LUKASZ MARCHEL

Polish Naval Academy, Gdynia, Poland

\title{
AUTOMATIC DETERMINATION OF CAR MOVEMENT PARAMETERS BASED ON IMAGE DETECTION
}

\begin{abstract}
This article presents alternative way of distance measurement to the preceding vehicle. Investigations were conducted for the purpose of assessing the possibility of using automatic determination of a car plate size in a photograph picture, and basing on that computing range to a vehicle. The first part describes the research methodology relating to angular measurements made with a still camera, The second part includes the method employed to automatically detect area occupied by a registration plate in a picture of a vehicle. The final part contains the mechanism of calculating distance to a car and the results of the investigation which justify using described method as a tool for range measurement.
\end{abstract}

Keywords:

remote sensing, autonomy, photo-based measurements.

\section{INTRODUCTION}

Interdisciplinary character of navigation inspires to derive from different kinds of science fields. An example of that trend is crossing it over with photogrammetry. One of the most popular area that photogrammetry is fixing attention on is face detection techniques [Mandal, 2014], [Akhand, 2016]. The technology is implemented to modern computers1, handheld devices and financial security. Developed methods give a wide range of applications. One of them is a car autonomy [Levinson, 2011], [Urmson, 2008] [Guizzol, 2011]. A whole word pay attention to recent innovations made by car makers. Especially Tesla, Google 
and BMW made a milestone in car autonomous driving [Guizzol, 2011], [Lamberd, online]. Adaptive cruise control modules mounted in vehicles have used LIDAR sensors [Kirchner, 2000], [Streller, 2002] single camera [Ritesh, 2013] and stereoscopic cameras so far [Cheng, online]. There have been a few researches being conducted on using vision-based systems in car features detection [Nawaz, 2016], [Tianfu, online] and car plate detection [Mousavi, 2014] used mainly for automatic recognition of plate numbers. The automatic registration plate recognition has been developed since 1990s. There are a few approaches to accomplish detection such us morphological based detection focused on a plate symmetry, and contrast feature extraction [Jun-Wei, 2002] or boundary-based approach and texture recognition algorithms [Tran, 2005]. The article presents alternative way of distance measurement to the preceding vehicle. Due to the fact that car plates have been standardized in Poland and the whole European Union, it was assumed that there is a possibility of range measurement based on photogrammetric methods. It was assumed that the automatic detection system will be fed with high resolution camera pictures. Due to the optical lens errors, program's module will undistort images. The OPENCV's calibrateCamera procedure was used with a standard chess pattern. This application is widely used in professional solutions and photogrammetric researches [Zawieska, 2016]. Next step will be conducted with an application programed in Visual Studio 2013 in C++ language with OPENCV library (2.43 version) included [http://www.opencv.org]. The pictures will be processed on one bit images and then computed and filtered. That process will help to extract areas of possible registration plate existence. Areas of interest will be resized to $140 \times 30$ pixel tiles and then processed with the Vector Support Machine classifier. Characteristic of the self-learning algorithm let to categorize plate and non-plate tiles. Automatical angular measurement will be conducted on a detected plate area. Based on computed values distance to a car will be calculated. Presented solution is a fusion of known detection patterns using morphological operations, classic line and features detection techniques and also SVM algorithm. It was developed not to detect a registration plate but to precisely and efficiently determine the white space area that will cropped and measured in terms of the width and angle.

\section{THE INVESTIGATION METHOD}

The aim of the investigations was to evaluate the accuracy of computed distance derived from the detected registration plate area. The pictures were taken 
using high class reflex digital camera Sony A390 equipped with Sony SAL1855 lens with focal length of $18-55 \mathrm{~mm}$. Measuring instrument is characterized by 14.2 Min of effective CCD matrix points. The photographic camera was placed on a still ground with the optical axis parallel to the ground surface and perpendicular to the registration plate of a car. To diversify results the pictures were taken from the distance 1 to $4 \mathrm{~m}$. The outcomes of the investigation were confronted with the measurement made with a digital laser measure Bosch Zamo, whose the mean error did not exceed $3 \mathrm{~mm}$.

To evaluate versatility of the registration plate recognition module, a series of pictures were taken of different vehicle types. The cars were characterized by various types of body colors and framing type. The test was narrowed to cars equipped with standard rectangular, single row registration plates (size of $520 \times 114 \mathrm{~mm}$ ).

a)

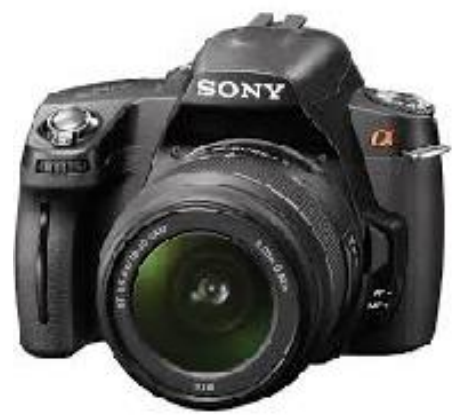

b)

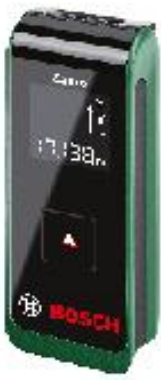

Fig. 1. Sony A390 (a), BOSCH ZAMO (b)

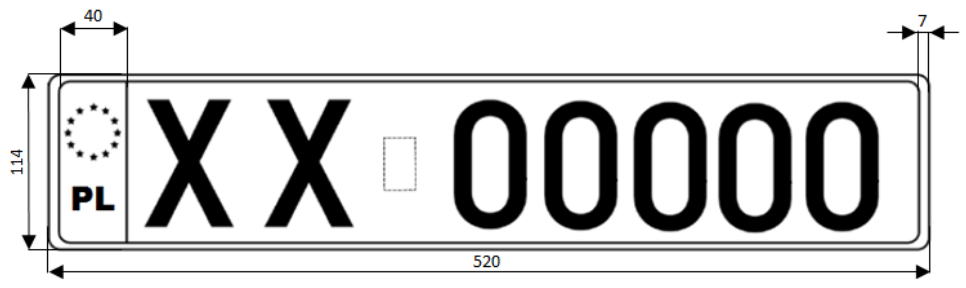

Fig. 2. Standard registration plate in Poland

\section{AUTOMATIC DETECTION METHOD}

It was a special program developed to detect registration plate area. The application was based on specific features of OPENCV library such as binaryzation, 
edge detection, morphologic operations. To extract regions of interest with the high possibility of plate existence there were several operations conducted. First of all the picture was processed to a binary image. Next step was application of Gaussian Blur. Implementation of that filter consequences in bias reduction in the picture. The operation consisted in attributing each pixel a new color value.

Due to rectangular shape of registration plate it was reasonable to take advantage of Sobel filter. It belongs to the family of convolution filters which computes pixel value basing on values of adjacent points. The task of this operator is to calculate directional derivates of picture intensity. The results of the filtering is finding edges in the processed picture [Tadeusiewicz, 1997]. This operation involves multiplying each pixel value by specific mask.

The next step in segmenting image was to threshold picture. The Otsu method was adopted. The outcomes of this operation usually represents an optimal value. In this specific type to compute the threshold value interclass variation is taken into account. A Background and an object is considered to be classes in that method. After implementation of thresholding binary picture was made [Wilczewski, online]. Applied method gives optimal results for images that are characterized by bimodal histograms (values of pixels are represented by two overlapping normal distributions).

Through the use of morphological dilation operation blank areas between vertical lines were minimalized and spaces with high density of edges were connected. That technique made possible to isolate regions with high possibility of a registration plate existence. Morphological operation takes advantage of the structuring element $(3 \times 3$ pixel) that is moved through a digital image. In case of a match a picture is modified by superposition 4 x 16 pixel mask. The size of the element is the approximated registration plate proportion. Contours on extracted areas were detected. It was assumed that processed regions have to be continuous. Detected tiles were reshaped to the form of a rectangle with RotatedRect operator (OPENCV library function). Thus created regions were validated on the figuration. Tiles without proportion of registration plate were rejected.

Extracted regions were transformed into 140 on 30 pixel rectangles. The areas were transferred into SVM algorithm. The classifier based on the pre-prepared database was to decide whether a processed tile is a registration plate or a false region. Database consists of 60 positive plates (pre-detected with used algorithm with different types of vehicles) and 60 negative objects (non-plates detected with used algorithm). After successful recognition of an object by SVM algorithm, area of the tile was cut from the original image. 
1

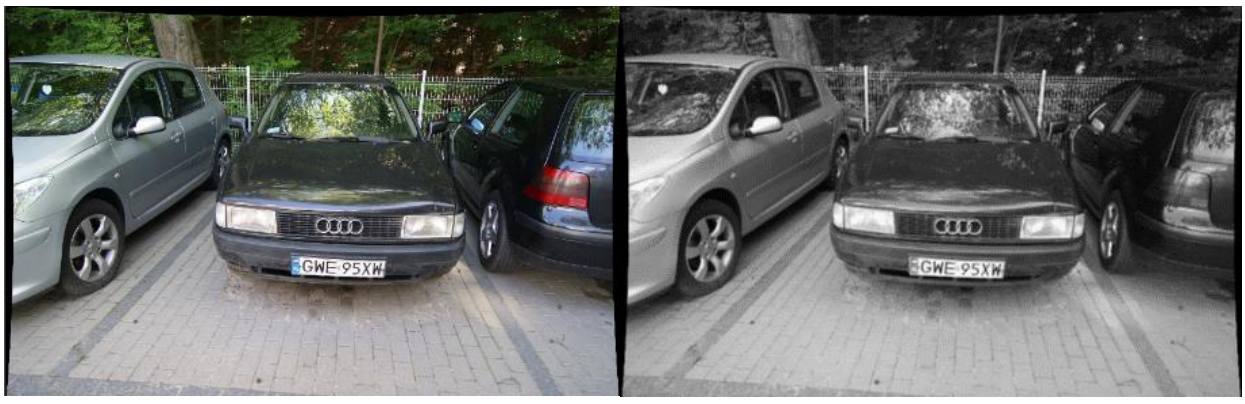

3

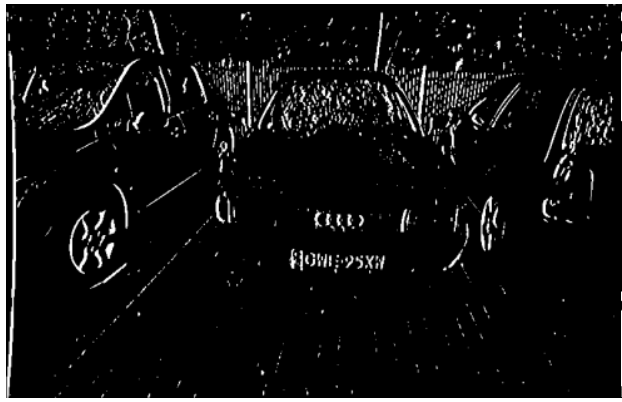

5

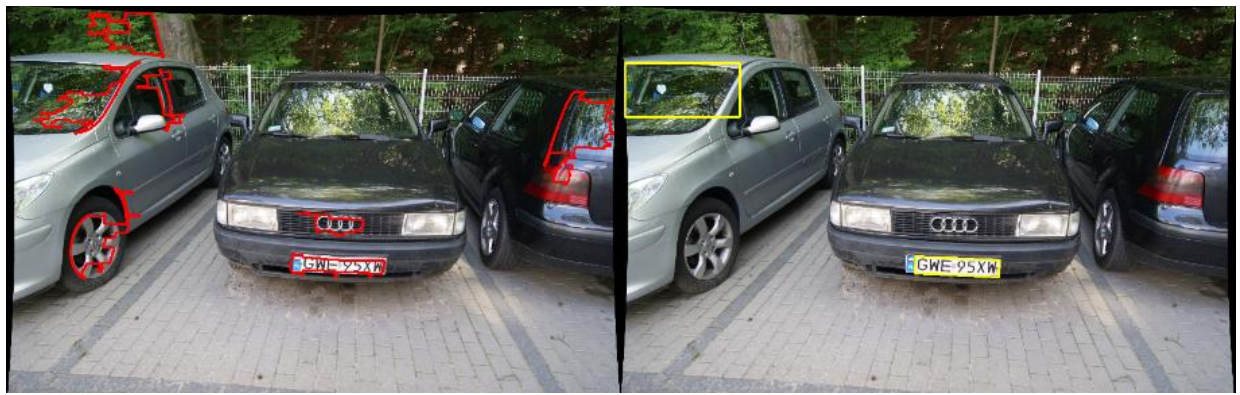

Fig. 3. Results of image segmentation: 1 - original image, 2 - bit image,

3 - Sobel transformation, 4 - picture after morphological operation,

5 - detected contours, 6 - validated tiles prepared to SVM classification
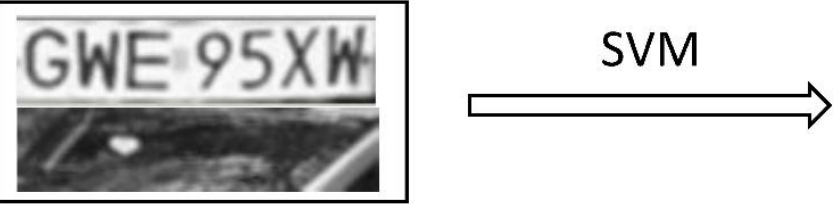

GWE 95XW

Fig. 4. Classification of the detected region 


\section{DISTANCE CALCULATION METHOD AND INVESTIGATION OUTCOME}

In the investigation it is assumed that optical axis of the photo camera will be placed in the middle of the object. Measure instrument will be placed parallel to the ground. Two cars are taken into measurement. First of them is light blue VW GOLF MK5 and the second is navy blue VW PASSAT B5. In the first place, the horizontal angle of a detected plate is calculated due to the formula:

$$
\alpha=\operatorname{arctg}\left(\frac{\Delta W_{p} \cdot W_{m}}{2 f \cdot W_{p}}\right) \text {. }
$$

Secondly, basing on the computed value, distance to the object is calculated according to the equation:

$$
S=\frac{W_{m}}{2 \cdot \operatorname{tg} \alpha}
$$

where:

$S$ - distance to the car,

$W_{m}$ - wide of CCD matrix in $\mathrm{mm}$,

$W_{p}$ - wide of CCD matrix in pixels,

$\Delta W_{p}$ - difference between points $x_{1}$ and $x_{2}$ on the picture.

In order to carry out the investigation, fourteen measurements were used (per seven for each car). They had been taken from distance 1 to 4 meters. The range was determined to make the whole car's body visible in the picture. The results obtained are presented in Tables 1 and 2. To run the application PC middle-class computer was used. It was equipped with Intel i7-2600S CPU, integrated video card Intel HD Graphics and 8 GB of RAM.

Tab. 1. The investigation results made with light blue VW GOLF

\begin{tabular}{|c|c|c|c|c|}
\hline $\begin{array}{c}\text { Measurement } \\
\text { number }\end{array}$ & $\begin{array}{c}\text { Laser distance } \\
\text { measurement } \\
{[\mathrm{mm}]}\end{array}$ & $\begin{array}{c}\text { Distance computed } \\
\text { with object detection } \\
{[\mathrm{mm}]}\end{array}$ & $\begin{array}{c}\text { Ratio of distance } \\
\text { computed to distance } \\
\text { measured }\end{array}$ & $\begin{array}{c}\text { Processing } \\
\text { time } \\
{[\mathrm{s}]}\end{array}$ \\
\hline 1 & 1002 & 1007 & 1.004 & 0.56 \\
\hline 2 & 1503 & 1516 & 1.008 & 0.58 \\
\hline 3 & 1998 & 1861 & 0.931 & 0.61 \\
\hline 4 & 2503 & 2626 & 1.049 & 0.49 \\
\hline 5 & 3001 & 3197 & 1.065 & 0.55 \\
\hline 6 & 3504 & 3723 & 1.062 & 0.49 \\
\hline 7 & 3999 & 3819 & 0.954 & 0.53 \\
\hline
\end{tabular}


Tab. 2. The investigation results made with navy blue VW PASSAT

\begin{tabular}{|c|c|c|c|c|}
\hline $\begin{array}{c}\text { Measurement } \\
\text { number }\end{array}$ & $\begin{array}{c}\text { Laser distance } \\
\text { measurement } \\
{[\mathrm{mm}]}\end{array}$ & $\begin{array}{c}\text { Distance computed } \\
\text { with object detection } \\
{[\mathrm{mm}]}\end{array}$ & $\begin{array}{c}\text { Ratio of distance } \\
\text { computed to distance } \\
\text { measured }\end{array}$ & $\begin{array}{c}\text { Processing } \\
\text { time } \\
{[\mathrm{s}]}\end{array}$ \\
\hline 1 & 998 & 1021 & 1.023 & 0.51 \\
\hline 2 & 1504 & 1589 & 1.056 & 0.53 \\
\hline 3 & 2001 & 2131 & 1.649 & 0.61 \\
\hline 4 & 2505 & 2673 & 1.067 & 0.47 \\
\hline 5 & 2998 & plate not detected & - & - \\
\hline 6 & 3508 & 3870 & 1.103 & 0.48 \\
\hline 7 & 4006 & 4389 & 1,095 & 0.43 \\
\hline
\end{tabular}

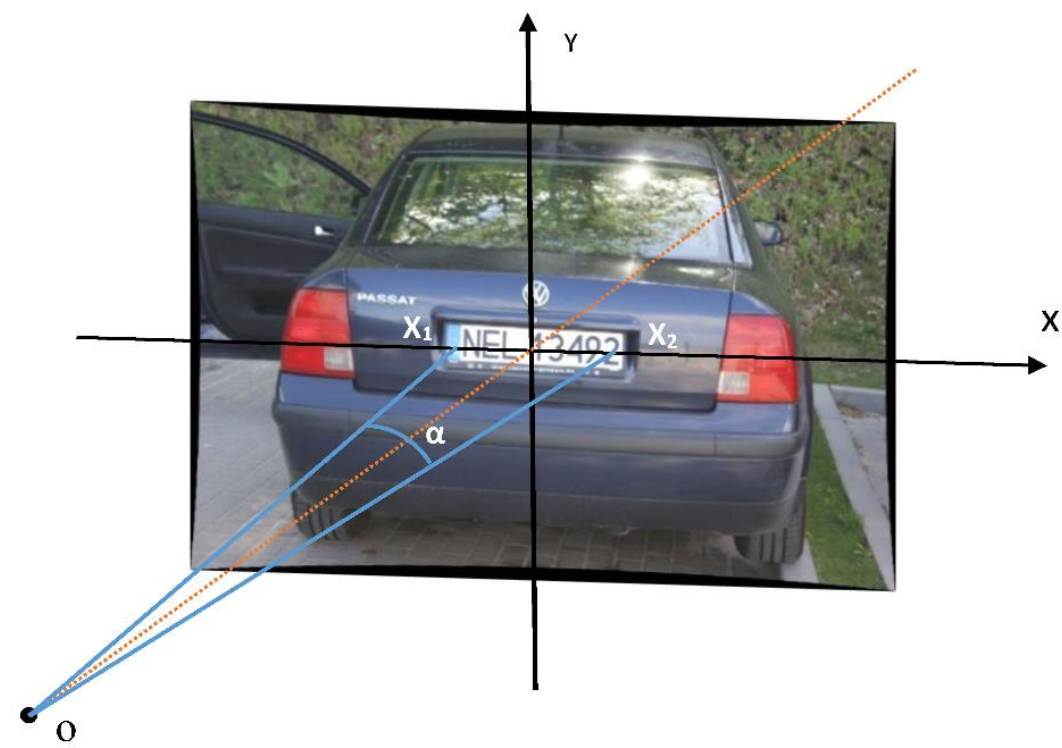

Fig. 5. Method of a horizontal angle determination: $X_{1}$ - outermost pixel from the left hand side, $\mathrm{X}_{2}$ - outermost pixel from the right hand side, $\alpha$ - angle measured from the perspective center, $\mathrm{O}$ - perspective center

Following the investigation results presented in Tables 1 and 2 , it can be claimed that:

- the distance values determined using laser measure differ from values computed on average by $3.97 \%$;

- in 11 cases the computer program calculated a greater distance then the laser measure; 
- the method of object detection proved to be effective at the level of 93\%, because 13 of 14 plates were detected;

- to make the used object detection method more effective it is reasonable to use automatic focal length adjustment to zoom on a registration plate;

- to make the method more effective it should be expanded on the motorcycle two row registration plate type detection;

- the object detection algorithm can be easily implemented to different solutions such as automatic plate numbers detection;

- average time of plate detection and distance computing from single picture was $0.53 \mathrm{~s}$;

- there is a need of use of GPU unit to enhance processing time.

\section{CONCLUSIONS}

To make vehicles autonomy more and more efficient requires focusing attention on various methods of determination movement parameters of the car itself but also others participants in road traffic. Presented, in the article, the algorithm of distance measurement may become one of the supplementary method in adaptive cruise control systems. Outcomes of the investigation shows that the developed method is efficient but requires some improvements. Optimization should be performed for system component miniaturization but also for improvement of programmed modules and time of distance computing. It can be stated that the development of areas connected with computers and optical mechanisms enables these improvements without a large financial expenditure. Because of high efficiency of OPENCV library it can be foreseen that the employed method would be able to run on RTLS bases with GPU units. Discrepancies recorded in the course of the results have a systemic nature. These errors could have been caused by imperfections of the optical mechanisms used in the photo camera.

\section{REFERENCES}

[1] Akhand M., Improvement of Haar Feature Based Face Detection in OpenCV Incorporating Human Skin Color Characteristic, Tetuan 2016.

[2] Cheng S., Stereo Vision in Autonomous Car Application, [online], www.stacks.stanford.edu/ file/druid:ys177gb6618/Chen_Theodosis_Wilson_Stereo_Vision_in_Autonomous_Car_ Application.pdf [access 10.10.2016]. 
[3] Curtis D., Electric and Hybrid Cars: A History, McFarland 2005.

[4] Guizzol I., How Google's self-driving car works, IEEE, San Francisco 2011.

[5] Jun-Wei H., Morphology-based License Plate Detection from Comlex Scenes, Conference paper, Canada 2002, pp. 176-179.

[6] Kirchner A., Integrated obstacle and road tracking using a laser scanner, Intelligent Vehicles Symposium paper, 2000, pp. 675-681.

[7] Lamberd F., Google's self-driving car vs Tesla Autopilot: $1.5 \mathrm{M}$ miles in 6 years vs $47 \mathrm{M}$ miles in 6 months, [online], www.electrek.co/2016/04/11/google-selfdriving-car-tesla-autopilot [access 04.11.2016].

[8] Langaniere R., OpenCV 2 Computer Vision Application Programming Cookbook, Pact publishing, Birmingham 2011.

[9] Lelis D., Mastering OpenCV with Practical Computer Vision Projects, Pact publishing, Birmingham 2012.

[10] Levinson J., Towards fully autonomous driving systems and algorithms, Intelligent vehicles symposium paper, 2011, pp. 1-6.

[11] Mandal B., A Wearable Face Recognition System on Google Glass for Assisting Social Interactions, ACCV, Singapore 2014.

[12] Mousavi S., Car Plate Segmentation Based on Morphological and Labeling Approach, Conference paper, Secunderabad 2014, pp. 84-87.

[13] Naus K., The still picture as a tool for angular measurement of surface object in an off-shore area, Zeszyty Naukowe Akademii Marynarki Wojennej, Gdynia 2015.

[14] Nawaz S., HOG-SVM Car Detection on an Embadded GPU, Eindhoven 2016.

[15] Open Source Computer Vision, [online], http://www.opencv.org, [access 10.10.2016].

[16] Ritesh K., Vision-Based Adaptive Cruise Control Using Pattern Matching, Conference paper, Durbanm 2013, pp. 40-46.

[17] Streller D., Vehicle and object models for robust tracking in traffic scenes using laser range images, International Conference on Intelligent Transportation Systems, 2002, pp. 118-123.

[18] Tadeusiewicz R., Computer analysis and image computing, [in Polish], WFPT, Kraków 1997.

[19] Tianfu W., Recognizing Car Fluents From Video, [online], www.researchgate.net/ publication/301836952_Recognizing_Car_Fluents_from_Video [access 10.10.2016].

[20] Tran D., Building an Automatic Vehicle License-Plate Recognition System, Conference paper, Can Thom 2005, pp. 59-63.

[21] Urmson C., Autonomous Driving in Urban Environments: Boss and the Urban Challange, 'Journal of a Field Robotics', 2008, Vol. 25, No. 8, pp. 525-566.

[22] Wilczewski M., Method of picture binarization, [online], http://www.mif.pg.gda.pl/ homepages/marcin/Wyklad3.pdf [access 10.10.2016].

[23] Zawieska D., The New Approach to Camera Calibration - GCPs or TLS Data?, Conference paper, Prague 2016, pp. 75-82. 
Received September 2016

Reviewed December 2016

LUKASZ MARCHEL

Polish Naval Academy

Śmidowicza 69 Str., 81-127 Gdynia, Poland

l.marchel@amw.gdynia.pl

\section{STRESZCZENIE}

W artykule przedstawiono alternatywny sposób pozyskiwania odległości do poprzedzającego pojazdu. Przeprowadzono badania mające na celu ocenę możliwości automatycznego wyznaczania rozmiaru rejestracji samochodowej na zdjęciu fotograficznym i na tej podstawie pomiaru odległości do pojazdu. W pierwszej części opisano metodę badań związaną z oceną dokładnościową pomiarów kąta i wyznaczania odległości wykonanych aparatem fotograficznym. W części drugiej przedstawiono sposób automatycznej detekcji obszarów zajmowanych przez rejestrację samochodową na zdjęciu pojazdu. Ostatnia cześć zawiera zasadę wyznaczania odległości do pojazdu oraz wyniki pomiarów z przeprowadzonych badań, potwierdzających zasadność stosowania opracowanego sposobu jako narzędzia do pomiarów odległości na podstawie elementów poddawanych automatycznej teledetekcji. 